\title{
Gaining Competitive Advantage at Sea: An Overview of Shipping Lines' Strategic Decisions
}

\author{
Enrico D'agostini ${ }^{1}$, Hyung-Sik Nam ${ }^{2,}$, , Seog-Hwan Kang ${ }^{2}$ \\ ${ }^{1}$ Department of International Logistics, Tongmyong University, Busan, Korea \\ ${ }^{2}$ Department of Shipping Management, Korea Maritime and Ocean University, Busan, Korea \\ Email address: \\ enrico@tu.ac.kr(Enrico D.), hsnam0215@kmou.ac.kr (Hyung-Sik N.), shkang@kmou.ac.kr (Seog-Hwan K.) \\ ${ }^{*}$ Corresponding author
}

\section{To cite this article:}

Enrico D'agostini, Hyung-Sik Nam, Seog-Hwan Kang. Gaining Competitive Advantage at Sea: An Overview of Shipping Lines' Strategic Decisions. International Journal of Transportation Engineering and Technology. Vol. 5, No. 4, 2019, pp. 74-81.

doi: $10.11648 /$ j.ijtet.20190504.12

Received: October 4, 2019; Accepted: October 24, 2019; Published: October 31, 2019

\begin{abstract}
The liner shipping sector has significantly changed in recent years. Largest shipping lines have expanded their business scope becoming global carriers and a recent wave of industry consolidation has profoundly modified the market structure and, consequently, the business models followed by liners. This, coupled with weak market fundamentals, generally poor balance sheets, and ordering of increasingly larger container vessels, has led each shipping line to follow a specific dominant strategy aimed at increasing market shares, margins and creating value for costumers. This article proposes an overview of the main market strategies pursued by the largest shipping lines. Through an analysis of major container lines strategies, the study aims at identifying what are the preferred strategies to gain competitive advantage. Particularly, the concept of diversification (product and geographical diversification), modes of diversification (internal and external), differentiation and concentration are comprehensively discussed and applied to the liner shipping industry. Furthermore, it tries explaining what are the most significant similarities and differences in market strategies in relation to the size of each shipping line. The review of our analysis suggests that 1 ) all shipping lines follow a hybrid strategic model with more than one individual strategy pursued 2) larger shipping lines prefer to diversify or differentiate 2) mid-sized shipping and smaller lines tend to pursue market concentration.
\end{abstract}

Keywords: Shipping Lines, Strategy, Diversification, Differentiation, Concentration

\section{Introduction}

In the past ten years, since the beginning of the global economic crisis, the liner shipping industry experienced significant and profound changes in terms of market volatility, network development and consolidation processes. Growth of demand in the container industry has slowed down since 2008, with particularly weak 2015 and 2016 , with only $1.1 \%$ and $3.1 \%$ growth in demand respectively. This coupled with a strong growth in supply had the effect to push downwards freight rates across all major trade lanes [1]. The prolonged negative impacts over major shipping lines produced weak balance sheets, which led to the implementation of different strategies to overcome the hardships. The search of cost reductions through slow steaming, a more rational network configuration and the search of economies of scale through the deployment of larger container ships are all strategies which have been widely implemented. Furthermore, the whole container industry was structurally changed due a wave of merger and acquisitions and new strategic alliances which reshaped the market structure and bargaining power of the actors across different regions.

In order to answer to these changes, each shipping line has adopted a unique market strategy. Shipping companies have tried gaining competitive advantage, or creating value to customers, in several ways. As indicated by Porter [2], corporations can gain competitive advantage through 1) price leadership or offering cheaper products then competitors or 2) differentiation, defined as the production of goods and services and perceived by customers as different from competitors [3] and 3) focus, with product or service aimed 
at specific market needs. Diversification is also a common strategy implemented by lines yet with significant differences in terms of product diversification, geography diversification and modes of diversification. In most cases, shipping lines implement a mix of these strategies, or a hybrid approach according to their strategic objectives, and financial capabilities. This is not uncommon as shown in previous research for other industries like the hospitality sector [4] and in manufacturing operations [5].

The objective of this paper is to identify and review shipping lines' strategies. In particular, the concepts of diversification, differentiation and concentration are analysed for major shipping lines and a link between strategy pursued and size of the corporation is proposed. The paper is organized as follow: section 2 depicts a general overview of major shipping lines, section 3 is about diversification and modes of diversification, section 4 deals with differentiation strategies, section 5 focuses on market concentration section 6 is on the discussion of the analysis and section 7 concludes the paper.

\section{Shipping Lines Overview}

Liner shipping is indisputably one of the most internationalized service-based industries. Since the beginning of containerization, where the main business was to move boxes from port to port, containerized trade has become much broader and complex. As globalized economy deepened, just-in-time requirements, lead time reductions, outsourcing and mass productions were major factors in setting new requirements within the logistics industry. Shipping lines played a major role in containerized trade by configuring complex networks of ships, terminal operations (vertical integration) at ports and, in some instances, inland transport services. Although there are some regional orientations by lines, shipping lines generally can be defined as global carriers, or logistics operators offering logistics solutions to their customers through shipping networks [6].

Shipping lines are commonly categorized according to their size, expressed in terms of fleet capacity and measured in TEU. Table 1 shows the top eleven shipping lines, their fleet capacity and related market share. Shipping lines can be grouped as large, mid-sized and small. Large shipping lines are Maersk with a capacity of $4,184,141$ TEU and a market share of $17.9 \%$; Msc (Mediterranean Shipping Company) with 3,599,064 TEU and a market share of $15.4 \%$; Cosco ranking third with 2,970,742 TEU and $12.7 \%$ market share and CMA-CGM (Compagnie Maritime d'Affrètement-Compagnie Générale Maritime) with 2,706,022 TEU and a market share of $11.6 \%$. They all have a market share above $10 \%$ and combined they control $57.6 \%$ of the whole container market. Mid-sized shipping lines include Hapag- Lloyd, with a capacity of $1,684,563$ TEU and a market share of 7.2\%; ONE (Ocean Network Express), which is the new line formed by the merge of the Japanese carriers MOL (Mitsui O. S. K. Lines), NYK (Nippon Yusen), K Line
(Kawasaki Kisen Kabushiki-Gaisha), has a capacity of 1,582,848 TEU and $6.8 \%$ market share and Evergreen, with 1,304,956 TEU and 5.6\% market share. They all fall between $5 \%$ and $10 \%$ market share range and in aggregate they control $19.6 \%$ of the market. Those lines with a market share less than $5 \%$ can be grouped as small shipping lines although their business scale and network is global. They include Yang Ming with 640,963 TEU and 2.7\% market share, HMM (Hyundai Merchant Marine) with 401,140 TEU and 1.7\% market share, PIL (Pacific International Line) with 386,892 TEU and $1.7 \%$ market share. Zim ranks $11^{\text {th }}$ and controls $1.2 \%$ of market share.

Table 1. Fleet capacity in TEU and market share of top 11 shipping lines.

\begin{tabular}{llll}
\hline Rank & Operator & TEU & Share \\
\hline 1 & Maersk & $4,184,141$ & $17.9 \%$ \\
2 & Msc & $3,599,064$ & $15.4 \%$ \\
3 & Cosco & $2,970,742$ & $12.7 \%$ \\
4 & CMA CGM & $2,706,022$ & $11.6 \%$ \\
5 & Hapag-Lloyd & $1,684,563$ & $7.2 \%$ \\
6 & ONE & $1,582,848$ & $6.8 \%$ \\
7 & Evergreen & $1,304,956$ & $5.6 \%$ \\
8 & Yang Ming & 640,963 & $2.7 \%$ \\
9 & Hyundai M. M & 401,140 & $1.7 \%$ \\
10 & PIL & 386,892 & $1.7 \%$ \\
11 & ZIM & 291,468 & $1.2 \%$ \\
& Total & $19,752,799$ & $84.5 \%$ \\
\hline
\end{tabular}

Source: Alphaliner top 100.

\section{Diversification}

The concept of diversification has been given a great deal of attention by researchers over the years. Diversification can be defined both under the view of product diversification and geographical diversification. Product diversification has been defined as a tool to reduce risks or as an option to select, under significant uncertainty, products and markets [7]. It has also been defined as the creation of new products into new target markets [8] and the level of market and product involvement for a corporation [9].

From an economic perspective, stakeholders in a corporation can benefit from diversification when there is portfolio of several assets. Some research indicates that there is a positive correlation, mainly because of scale economies and risk reduction, between degree of diversification and financial performance $[10,11]$. Nevertheless, in some cases this link may not be so evident, with some publications indicating that highly diversified corporations can generate low profitability [12, 13], decreased shareholder value [14] and firm value [15].

Diversification can also take on the form of geographical diversification [16] and it has been discussed across several sectors. In the banking sector, diversification has been a focal point in determining the relationship between geographical diversification and insolvencies [17] or geographical diversification and bank holding value [18]. In export trade, geographical diversification is seen as a potential driver of economic growth $[19,20]$, and international sales [21] as 
well as firms' performance [22]. The real estate sector was also investigated to test whether property diversification was better in a single region by type than between regions by type [23].

There are different factors leading to diversification strategies within a corporation. The motives to pursue a diversification strategy can be financial are different: as a tool to expand a business achieving scale economies [24], search for market shares [25], competition and market/economic structure [26, 27], managerial [28], internal corporate coordination issues [29] and disruptive technologies [30].

In the liner shipping context, diversification is one of the most important strategies for shipping companies and it is overall pursued by most of the largest lines [31] in order to avoid freight rates volatility and market cyclicality [32]. In terms of product diversification, we can argue that ships' types are the way in which shipping lines hedge market risks. With a portfolio of different assets (ship types), shipping lines acquire the ability to operate in markets which are not strictly correlated to container trades and hedge market risks. Arguably, the most diversified shipping line in terms of ships type is Cosco shipping. Currently, it operates a fleet of LNG vessels, ore carrier, heavy lift ships, bulk carrier, tankers, chemical carriers, product tankers, general cargo ships, ferries and container ships. Overall, considering ships in service and on order Cosco fleet comprises 900 ships [33]. The container segment represents a very important share with 482 container ships operated, 176 of which owned and 306 chartered [34]. Msc, the Swiss based shipping company, followed a different strategy as they focused only on container ships within the merchant sector but entered into the passengers market with Msc cruise and it is the only top shipping line currently operating in the cruise industry. Although smaller in terms of fleet capacity, HMM operates container ships as well as tankers, bulk carriers and chemical carriers [33].

On the other hand, liner shipping network can be interpreted as the way in which shipping lines strategically deploy container ships in different regions or markets. Therefore, shipping lines can pursue a geographical diversification according to the number of lanes, frequency of service and market covered. The fleet size of a single shipping line plays a major role in the liner shipping network configuration. Larger lines are facilitated in global operations given the larger number of ships whilst smaller operators are more regionally oriented and due to limited resources focus on niche markets [31]. Examples of lines which pursue global coverage are Maersk, Msc, Cosco, CMA-CGM, Hapag-Lloyd, ONE and Evergreen.

Shipping companies have different options to develop resources needed to pursue a diversification strategy. These options are often referred as internal development, acquisitions or alliances [35]. Rumelt [36] interprets diversification as a strategy to increase related products and services to the core business. In shipping, increasing related products and services is represented by growth in fleet capacity. Both internal developments and merger and acquisitions (M\&A) can lead to increase in fleet capacity for shipping lines.

Internal growth of shipping lines is achieved either through new orders or chartering vessels. As argued by Cariou [37] each strategy has some advantages and drawbacks. New orders strategy may depends by factors as capacity of rising capital, market reputation, relationship with banks, corporate financial structure and capabilities. In some cases, new orders are the mode in which shipowner can strategically reduce the average age of the fleet and increase vessels' performance with the use of latest available technology. Table 2 indicates the current orderbook of major shipping lines. Maersk and Cosco have currently low orderbooks, respectively at $0.7 \%$ and $0.2 \%$ of the existing fleet. However, both of them have recently been involved in acquisitions; Maersk acquired Hamburg Sud and Cosco acquired OOC which may partially explain why only few ships are on order. CMA-CGM has $14.9 \%$ of its current capacity on order for a total of 27 ships. Evergreen, Yang Ming and HMM are the lines with the highest orderbook, respectively of $25.7 \%, 30.9 \%$ and $98.7 \%$. HMM in particular is expected to double its capacity in a few years with the heavy support of the Korean government [38]. The average vessel size on order is 19,800 TEU $(396,000$ TEU divided 20 ships) which indicates a strategy of the Korean line pursued to remain competitive across main trade lanes, particularly the transpacific.

Table 2. Current orderbook of top 11 shipping lines.

\begin{tabular}{lllll}
\hline \multirow{2}{*}{ Rank } & Operator & Orderbook & & \\
\cline { 3 - 5 } & & TEU & Ships & \% Existing \\
\hline 1 & Maersk & 28,640 & 13 & $0.7 \%$ \\
2 & Msc & 237,764 & 13 & $6.6 \%$ \\
3 & Cosco & 5,250 & 3 & $0.2 \%$ \\
4 & CMA CGM & 403,562 & 27 & $14.9 \%$ \\
5 & Hapag-Lloyd & & & \\
6 & ONE & & & \\
7 & Evergreen & 336,544 & 58 & $25.8 \%$ \\
8 & Yang Ming & 198,100 & 24 & $30.9 \%$ \\
9 & Hyundai M. M & 396,000 & 20 & $98.7 \%$ \\
10 & PIL & & & \\
11 & ZIM & & & \\
\hline
\end{tabular}

Source: Alphaliner top100.

On the other hand, chartering provides a more flexible solution as ships are almost immediately available and capital required is lower. Nevertheless, this may be more expensive in the mid and long-run [37]. Table 3 shows the shares of owned and chartered ships by the top eleven shipping lines. Comparing the two largest shipping lines, Maersk and Msc, it is evident how chartering strategies substantially differ. Maersk charter only $43.8 \%$ of the ships it operates whilst Msc has chartered $69.9 \%$ of ships. Since its impressive growth, Msc has been ordering and chartering ships as the favourite mode to increase fleet capacity. Yang Ming, HMM and ZIM are also lines which preferred an organic growth strategy rather than $\mathrm{M} \& \mathrm{~A}$.

Hapag-Lloyd has the lowest share of chartered ships with $37.5 \%$ and ZIM the highest with $93.9 \%$ of ships on charter. 
Therefore, there are major differences in strategies related to the question of owning or chartering ships among shipping lines.

Table 3. Shares of owned and chartered ships by top 11 shipping lines.

\begin{tabular}{llllll}
\hline \multirow{2}{*}{ Rank } & \multirow{2}{*}{ Operator } & Total & Owned & \multicolumn{2}{l}{ Chartered } \\
\cline { 5 - 6 } & & Ships & Ships & Ships & \% \\
\hline 1 & Maersk & 713 & 316 & 397 & $43.8 \%$ \\
2 & Msc & 557 & 182 & 375 & $69.9 \%$ \\
3 & Cosco & 482 & 176 & 306 & $47.3 \%$ \\
4 & CMA CGM & 511 & 127 & 384 & $62.8 \%$ \\
5 & Hapag-Lloyd & 234 & 112 & 122 & $37.5 \%$ \\
6 & ONE & 220 & 74 & 146 & $65.8 \%$ \\
7 & Evergreen & 206 & 113 & 93 & $56.1 \%$ \\
8 & Yang Ming & 98 & 41 & 57 & $70.7 \%$ \\
9 & Hyundai M. M & 65 & 14 & 51 & $67.7 \%$ \\
10 & PIL & 119 & 70 & 49 & $58.5 \%$ \\
11 & ZIM & 64 & 4 & 60 & $93.9 \%$ \\
\hline
\end{tabular}

Source: Alphaliner top100.

Merger and acquisition and alliances are main drivers for external growth [37] and diversification [39]. The year 2016 has been a year in which merger and acquisition have reshaped the container trade market structure and today the top ten shipping lines control almost $90 \%$ of the market [40]. For instance, Maersk acquired Hamburg-Sud, a move which allowed gaining market share in the North-South route and diversify both in terms of geographical region (Transatlantic trade) [41] as well as product given the strong specialization of Hamburg-Sud in cold chain logistics (reefer containers). Maersk, throughout its history (Sealand and Safmarine in 1999), has been traditionally one of the carrier that favoured growth through M\&A. CMA-CGM took over NOL whilst Cosco and China shipping merged together and took over OOCL enabling the Chinese carrier to rank $3^{\text {rd }}$ in fleet capacity. Hapag-Lloyd merged with UASC (United Arab Shipping Company) and Hanjin declared bankruptcy leaving HMM as the only Korean shipping line.

Strategic alliances are other important options for shipowners for improving the scope of their market coverage under slot charter agreements. Members of a strategic alliance are able to improve the quality and scope of their services by increasing frequency at ports of call, space availability and offering new routes without additional investments [37]. They deploy existing vessels of the respective fleets for a limited period of time in specific routes. Nevertheless, merger and acquisitions are main drivers of instability for alliances whose partners may be forces to exit or entry new alliance. As a strategic option, all major shipping lines are today member of a shipping alliance; the two largest Maersk and Msc formed 2M, CMA-CGM, Cosco, OOCL and Evergreen are part of the Ocean alliance whilst Hapag-Lloyd, ONE and Yang Ming are partners in THE Alliance. Smaller players like HMM, PIL and ZIM have strategic cooperation agreement with other lines in specific trade lanes. HMM, for instance, has a slot charter agreement with Maersk and Msc on key East-West routes [42]; PIL with Wan Hai Lines and K Line from South East Asia to US West
Coast [43]; ZIM has a slot sharing agreement with Maersk and MSc on the Asia-US trade [44]. Despite these agreements in place, they are not formally members of any of the three alliances.

\section{Differentiation}

Porter defined differentiation as the corporate production of goods and services perceived by customers as different from competitors [3]. When considering the shipping product, the ship, it is extremely difficult to achieve any sort of differentiation. Ships are nowadays built in a standardized way with almost the same specifications which led to forge the term "commoditization of shipping", defined by Merriam-Webster as "to render "a good or service" widely available and interchangeable with one provided by another" [45]. Since the era of alliances and vessels sharing agreement, where containers from different shipping lines have been transported on a same vessel, the concept of commoditization of shipping gained pace. Therefore, in some instances, it is very difficult to differentiate the service offered (transit time and frequency for instance) by a line with the one of competitor, with price as the only major factor of differentiation. Juga, Pekkarinen and Kilpala [46] highlights that it is increasing difficult to gain competitive advantage for liners. Within a firm, differentiation can take many shapes and dimension as it can include a product or service differentiation, marketing differentiation, customer service differentiation or technological differentiation [3]. In the shipping industry, previous studies confirm the wide areas in which differentiation strategies can be found. Lorange [47] suggests differentiation can be achieved through the development of human resources within the company, considering the market as a learning process and new technologies. Juga, Pekkarinen and Kilpala [46] further indicates that terminal operations and logistics services are modes of achieving differentiation. In line with Juga et al., Gadhia, Kotzab and Prockl [48] confirms differentiation includes offering door-to-door, intermodal and logistics services.

There are several reasons for shipping lines to enter into terminal operations; Cariou [37] indicated that the process of vertical integration took place as a complementary strategy to horizontal integration ( $\mathrm{M} \& \mathrm{~A}$ ) to gain control of the logistics chain. Terminal operations also helped lines to secure traffic and increase profitability on both the sea and the hinterland [49]. Maersk, for instance, is one of the most differentiated shipping line as they moved from a product diversification strategy after selling the oil and gas business and its tanker fleet in 2017 [50] to focus purely into the transport and logistics sector and becoming a "one stop shipper shop' offering door to door services and ability to compete with third party logistics firms such as DHL or UPS [51]. As part of a restructuring process, Maersk merged with global freight forwarder Damco with the objective in becoming an integrated container transport operator and to offer inclusive supply chain solution [52]. 
In addition, in 2019 Maersk operated a total of 78 terminal worldwide with a diversified portfolio in several regions; 16 in the Americas, 19 in Asia, 23 in Europe, Russia and Baltics and 20 in Africa and Middle East [53]. APM terminals, part of Maersk group, handled 76.3 million TEU representing 10.2 market share [54]. French line CMA-CGM has followed a very similar path with Maersk acquiring CEVA logistics and differentiating by offering integrated transport solutions [55]. The structure of terminal operations for CMA CGM is more complex as it comprises terminal links owned by CMA-CGM (51\%) and China Holdings International (49\%). They are mainly concentrated in Europe (7 terminals), USA ( 2 terminals), North Africa and Far East. In addition, CMACGM operated through CMQ terminals a total of 32 terminals complementing those operated under terminal link [56]. Furthermore, Maersk operates an extended network of rail and inland transportation on a global scale [53].

Cosco has also pursued differentiation in relation to terminal operations with a strong presence in China and overseas terminals in South Korea (Busan), Singapore, Middle East, Europe and the Americas [57]. Cosco is currently the largest terminal operator in the world with 91.3 million TEU moved in 2017 representing a 12.2\% market share [54]. Notwithstanding, the development of the Belt and Road Initiative (BRI) is expected to further increase the portfolio and geography of terminals operated. Cosco is both diversified and differentiated but diversification is currently the dominant strategy.

Notably, Maersk, CMA-CGM and Cosco operate a large number of terminals in different markets which indicate a geographical diversification within the process of vertical integration.

Hapag-Lloyd follows a very different approach; despite it is the $5^{\text {th }}$ largest shipping line, it has not invested in any terminals operations and follows a different approach compared to other lines [58]. Evergreen and Yang Ming, have a rather diversified portfolio of terminals ranging from Europe to Asia and America. Smaller lines, like HMM (4 terminals acquired through from former Hanjin), PIL and ZIM have few or no terminal operated. This shows a very different strategy due to the limited resources and the focus on niche markets of smaller players [31].

\section{Concentration}

Concentration is a vital strategy for smaller shipping lines. According to Carbone and Stone [39], it is a strategy which is expressed in terms of shipping routes and geographical coverage. Due to limited resources and a lower fleet capacity then large lines, smaller players decide to focus on specific regions, or niche markets where customer needs can be better understood. Niamie' and Germain [59] suggest that shipping lines can also concentrate though operating vessels on fewer shipping lanes with reduced port of calls as a way to maximize vessel space utilization. Lines that are highly concentrated on specific markets are mainly those with lower fleet capacity. For instance, shipping lines with a market share below 5\%, namely Yang Ming, HMM, PIL and ZIM have a strategic regional concentration. Yang Ming is a global carrier but it is particularly concentrated in the Far East region with services across Taiwan, China, South Korea and Japan. It also serves Canada, US west coast and Europe [60]. HMM has been traditionally concentrated in the transpacific as it operates terminals at both end in Busan and Los Angeles It is also serving niche market in South America, Russia and Australia [61]. PIL is another highly concentrated shipping lines with a strong market orientation in intra-Asia (South-East Asia and South Asia), Oceania and Micronesia market [62]. A niche market for ZIM is the Mediterranean region with several services connecting Asia, Black Sea, North America, North Europe, Intra Mediterranean and South America [63].

\section{Discussion}

The emergence of global carrier in the liner shipping industry has modified, under several aspects, the containerized trade industry. Presently, the liner shipping environment is very complex and competitive across routes and regions and it is of vital importance for liner to pursue a strategy aimed at hedging risk and gaining competitive advantage. Although each shipping line has a different history, culture, vision, objectives and limited resources, there are some market strategies which are commonly pursued. In our paper we reviewed some of the strategies that container lines implement as:

1. Product diversification (ship's types in the operated fleet).

2. Geographical diversification (routes and shipping markets).

3. Mode of diversification (internal or external growth).

4. Differentiation (vertical integration and logistics services offered).

5. Concentration (operations focused in a niche market).

In most cases, it is difficult to draw a conclusion on what is the dominant strategy of a shipping line. Most, if not, of container lines analysed in the paper, pursue a hybrid strategy model, which involves the combination of more than one individual strategy. Panayides showed similar findings applied to the ship management industry, and indicated that strong performers within the sector are those pursuing a mix of strategies rather than a single isolated strategy [64].

As an attempt to draw some conclusion on the main strategies adopted by lines, a summary of the dominant strategies pursued by shipping lines is proposed in figure 1 .

Larger shipping lines, which have more assets and resources to deploy, tend to diversify more than smaller lines in terms of ships' type operated (Msc and Cosco are highly diversified whilst CMA CGM, Hapag-Lloyd, Evergreen, Yang Ming, PIL and ZIM show low diversification) and geographical markets (Maersk, Msc, Cosco, CMA CGM, Hapag-Lloyd, ONE, Evergreen offer global coverage whilst Yang Ming, HMM, PIL, ZIM focus on niche markets) served.

From a freight forwarding perspective, further evidence is 
shown in the study by Markides and Holweg, in which a significant correlation is found between freight forwarders' size and level of diversification. Larger operators, and particularly those with a strong asset base, pursued diversification as dominant strategy compared to smaller companies [65]. The finding and implications are in line with the results proposed in this paper. As both industries face similar challenges in terms of increased competition and deep changes in market's structure, providing empirical evidence is needed for the identification of market strategies and patterns related to companies' size.

In addition, very large lines like Maersk and CMA CGM, are shifting deeply into differentiation, in which the core business is represented by integrated transport services. In terms of terminal operated, which is a way for liners to differentiate, large lines operate a wide number of terminals in several regions whilst smaller ones (HMM, PIL and ZIM) have limited or no terminals operated. They tend to concentrate on niche markets unlike larger players which tend to offer global services. There are significant differences in terms the mode of diversification, or the ways in which lines increase fleet capacity. Msc, Yang Ming, HMM and ZIM tend to prefer internal growth through new orders and chartering ships. On the other hand, Maersk, CMA CGM, Cosco and Hapag-Lloyd have historically been involved in merger and acquisitions to grow. Most of them have a lower than average percentage of chartered ships in the fleet.

\begin{tabular}{|c|c|c|}
\hline High & & Low \\
\hline $\mathrm{Cosco}, \mathrm{HMM}, \mathrm{Msc}$ & $\begin{array}{c}\text { Product } \\
\text { Diversification }\end{array}$ & $\begin{array}{c}\text { CMA-CGM, Hapag-Llyod } \\
\text { Evergreen, Yang Ming } \\
\text { PIL, ZIM }\end{array}$ \\
\hline $\begin{array}{l}\text { Maersk, MSC, Cosco } \\
\text { CMA-CGM, Hapag } \\
\text { Lloyd, One, Evergreen }\end{array}$ & $\begin{array}{c}\text { Geographical } \\
\text { Diversification }\end{array}$ & $\begin{array}{l}\text { Yang Ming, HMM } \\
\text { PIL, ZIM }\end{array}$ \\
\hline $\begin{array}{l}\text { Maersk, CMA CGM, } \\
\text { Hapag Lloyd }\end{array}$ & \multirow{2}{*}{$\begin{array}{l}\text { Differentiation } \\
\text { (Terminal } \\
\text { Operated) }\end{array}$} & One, Evergreen \\
\hline $\begin{array}{l}\text { Maersk, Msc, CMA- } \\
\text { CGM, Cosco }\end{array}$ & & HMM, PIL, ZIM \\
\hline $\begin{array}{l}\text { Yang Ming, HMM, } \\
\text { PIL, ZIM }\end{array}$ & Concentration & $\begin{array}{r}\text { Maersk, MSC, Cosco, } \\
\text { CMA CGM, Hapag Lloyd }\end{array}$ \\
\hline
\end{tabular}

\begin{tabular}{|c|c|c|}
\multicolumn{1}{|c}{$\begin{array}{c}\text { Internal } \\
\text { (New orders \& } \\
\text { Chartering) }\end{array}$} & $\begin{array}{c}\text { External } \\
\text { (M \& A) }\end{array}$ \\
\hline $\begin{array}{c}\text { Msc, Yang Ming, } \\
\text { HMM, ZIM }\end{array}$ & $\begin{array}{c}\text { Mode of } \\
\text { Diversification } \\
\text { (preferred) }\end{array}$ & $\begin{array}{c}\text { Maersk, CMA CGM, } \\
\text { Cosco, Hapag Lloyd }\end{array}$ \\
\hline
\end{tabular}

Figure 1. Summary of dominant strategies of shipping lines.

\section{Conclusion and Managerial Implications}

Increasingly, liner tend to approach the market with a strategic mix, where more than one individual strategy is overall implemented depending upon a specific context and business area. There are major differences as well as similarities in the strategic market approach for both larger and smaller lines. In our analysis it was interesting to note how larger shipping lines tend to diversify in several areas of business in a much broader way compared to smaller players and are increasingly shifting into a differentiation strategy. On the other hand, smaller players, which have limited resources, are mainly focusing on niche markets proving tailor-made services for their customers.

An understanding of liners' corporate strategies can play a major role for a wide number of logistics companies and organizations involved in containerized trade. Firstly, beneficial cargo owners should select shipping lines which best fit their needs in terms of cargo volumes, regions of trade, transportation needs and customer service. By knowing their strategies, they can be in a more favorable position in terms of negotiations and customer services requirements. Secondly, port managers and operators should not underestimate the importance of analysing liner strategies as it may affect their business directly or indirectly. Key factors for gaining competitive advantage from a port management perspective comprise the recognition and interpretation of what are the dominant strategies of their customers and how to adapt to satisfactory serve them. Lastly, third party logistics operators, freight forwarder and NVOCC should also be aware of liners' strategies as an increasing number of lines are shifting their business into integrated transport solutions. In some cases, shipping lines like Maersk and increasingly CMA CGM and Cosco might enter into direct competition with third party logistics operators and they may be able to react accordingly.

The future of the liner industry will most likely show further changes in the mode in which the market is approached by shipping lines and strategies are adopted. This will deeply depends on how market conditions change and competition behaves.

The objective of this paper was to provide an overview of market strategies pursued by major shipping lines and establishing a link between line's fleet capacity and dominant strategy. Although we have tried presenting some insights, there are a number of questions which remain open for future research. For instance, diversification as a strategy can be further deepened by investigation whether lines which have high rates of chartered ships in their fleet can hedge market risks by fixing vessels with different time charter party durations. Additionally, future research should address the question on whether a line can generate more profitability on a specific route comparing different strategies and what are the driving causes of change in market strategies for shipping lines.

\section{Acknowledgements}

The authors wish to express their gratitude to the anonymous referee of this journal for the valuable and constructive comments which contributed to enhance the quality of this paper. 


\section{References}

[1] UNCTAD., (2018). Review of Maritime Transport. New York, United Nation Publications.

[2] Porter, M. E., (1985). The Competitive Advantage: Creating and Sustaining Superior Performance. NY: Free Press.

[3] Porter, M. E., (1980). Competitive Strategy. New York: Free Press.

[4] Espino-Rodriguez, T., \& Chun-Lai, P., (2014). Activity Outsourcing and Competitive Strategy in the Hotel Industry. The Moderator Role of Asset Specificity. International Journal of Hospitality Management, Vol. 42, pp. 9-19.

[5] Hilman, H., \& Warokka, A. (2011). Malaysian Based Manufacturing Firms' Strategic Sourcing: A Test of Transaction Cost Economics Theory and Resource Based View. Journal of Outsourcing \& Organizational Information Management, pp. 1-10.

[6] Fremont, A., (2007). Global Maritime Networks: The Case of Maersk. Journal of Transport Geography, Vol. 15, pp. 431-442.

[7] Hitt, M. A., Hoskisson, R. E., Ireland, R. D., (1994). A midrange Theory of the Interactive Effects of International and Product Diversification on Innovation and Performance. Journal of Management, Vol. 20, pp. 297-327.

[8] Ansoff, I. H., (1957). Strategies for Diversification. Harvard Business Review, Vol. 35, No. 5, pp. 114-115.

[9] Kamien, M. I., \& Schwartz, N. L., (1975). Market Structures and Innovation: A Survey. Journal of Economic Literature, Vol. 13, No. 1, pp. 1-37.

[10] Christensen, H. K., \& Montgomery, C. A., (1981). Corporate Economic Performance: Diversification Strategy versus Market Structure. Strategic Management Journal, Vol. 2, pp. 327-44.

[11] Kor, Y. Y., \& Leblebici, H., (2005). How Do Interdependencies among Human-Capital Deployment, Development, and Diversification Strategies Affect Firms' Financial Performance? Strategic Management Journal, Vol. 26, No. 10, pp. 967-985.

[12] Lamont, O. A. \& Polk, C., (2002). Does Diversification Destroy Value? Evidence from the Industry Shocks. Journal of Financial Economics, Vol. 63, No. 1, pp. 51-57.

[13] Davis, P. S., Robinson, R. B., Pearce, J. A., Dan Park, S. H., (1992). Business Unit Relatedness and Performance: A look at the Pulp and Paper Industry. Strategic Management Journal, Vol. 13, pp. 349-361.

[14] Doukas, J. A., \& Kan, O. B., (2006). Does Global Diversification Destroy Firm Value? Journal in International Business Studies, Vol. 37, No. 3, pp. 352-371.

[15] Hyland, D., (2003). The Effect of Diversification on Firm Value: A Pre-and Post-Diversification Analysis. Studies in Economics and Finance, Vol. 21, No. 2, pp. 22-39.

[16] Deng, S., \& Elyasiani, E., (2008). Geographic Diversification, Bank Holding Company Value and Risk. Journal of Money, Credit and Banking, Vol. 40 No. 6, pp. 1217-38.

[17] Hughes, J. P., Lang, L., Mester, L. J., Moon, C. G., (1996).
Safety in Numbers? Geographic Diversification and Bank Insolvency Risks. Working paper No. 96-14.

[18] Goetz, M., \& Laeven, L., (2013). Identifying the Valuation Effects and Agency Costs of Corporate Diversification: Evidence from the Geographic Diversification of U.S. Banks. Review of Financial Studies, Vol. 26, No. 7, pp. 1787-1823.

[19] Hinlo, J. E., \& Arranguez, G. I. S., (2017). Export Geographical Diversification and Economic Growth among ASEAN Countries. MPRA Paper 81333, University Library of Munich, Germany.

[20] Dai, J., (2013). Efficient Geographical Diversification of Export Trade: The Case Study of China. In: Bian F., Xie Y., Cui X., Zeng Y. (eds). Geo-Informatics in Resource Management and Sustainable Ecosystem. GRMSE 2013. Communications in Computer and Information Science, vol 399. Springer, Berlin, Heidelberg.

[21] Cieślik, J., Kaciak, E., Welsh, D. H. B. (2012). The Impact of Geographic Diversification on Export Performance of Small and Medium-Sized Enterprises (SMEs). Journal of International Entrepreneurship, Vol. 10, No. 1, pp. 70-93.

[22] Boehe, D. M., \& Jimenez, A., (2016). How Does the Geographic Export Diversification-Performance Relationship Vary at Different Levels of Export Intensity? International Business Review, Vol. 25, Issue 6, pp. 1262-1272.

[23] Eichholtz, P. M. A., Hoesli, M., MacGregor, B. D., Nanthakumaran, N., (1995). Real estate Portfolio Diversification by Property Type and Region. Journal of Property Finance, Vol. 6 No. 3, pp. 39-59.

[24] Amit, R., \& Livnat, J., (1988). Diversification Strategies, Business Cycles and Economic Performance. Strategic Management Journal, Vol. 9, No. 2, pp. 99-110.

[25] Montgomery C. A., (1994). Corporate Diversification. Journal of Economic Perspectives, Vol. 8, pp. 163-178.

[26] Stern, I., \& Henderson, A. D., (2004). Within-Business Diversification in Technology-Intensive Industries. Strategic Management Journal, Vol. 25, pp. 487-505.

[27] Mayer, M., \& Whittington, R., (2003). Diversification in Context: A Cross-National and Cross-Temporal Extension. Strategic Management Journal, Vol. 24, No. 8, pp. 773-781.

[28] Palmer, D., \& Barber, M., (2001). Challengers, Elites and Owning Families: A Social Class Theory of Corporate Acquisitions in the 1960s. Administrative Science Quarterly, Vol. 46, pp. 87-120.

[29] Grossmann, V., 2007). Firm Size and Diversification: Multiproduct Firms in Asymmetric Oligopoly. International Journal of Industrial Organization, Vol. 25, pp. 51-67.

[30] Miller, D. J., (2006). Technological Diversity, Related Diversification, and Firm Performance. Strategic Management Journal, Vol. 27, pp. 601-619.

[31] Panayides, P. M., \& Wiedmer, R., (2011). Strategic Alliance in Container Liner Shipping. Research in transportation Economics, Vol. 32, pp. 25-38.

[32] Oswald, J., Ghobadian, A. O, Regan, N., Antcliff, V., (2013). Dynamic Capabilities in a Sixth Generation Family Firm: Entrepreneurship and the Bibby Line. Business History, Vol. 55, No. 6, pp. 910-941. 
[33] Clarkson Shipping Intelligence Network, (2019). Retrieved from https://sin.clarksons.net/.

[34] Alphaliner top 100, 2019. Retrieved from https://alphaliner.axsmarine.com/PublicTop100/.

[35] Villalonga, B., \& McGahan, A. M., (2005). The Choice among Acquisitions, Alliances and Divestitures. Strategic Management Journal, Vol. 26, pp. 1183-1208.

[36] Rumelt, R. P., (1974). Strategy, Structure, and Economic Performance. Cambridge MA: Harvard University Press.

[37] Cariou, P. (2007). Liner Shipping Strategies: An Overview. International Journal of Ocean Systems Management, Vol. 1, pp. 1-9.

[38] Dupin, C. (2017). HMM to Receive Support from South Korean Government. Retrieved from https://www.freightwaves.com/news/hmm-to-receive-supportfrom-south-korean-government

[39] Carbone, V., Stone, M.A., (2005), Growth and Relational Strategies Used by the European Logistics Service Providers: Rationale and Outcomes. Transportation Research Part E, Vol. 41, pp. 495-510.

[40] Top 10 Shipping Lines Control Almost 90\% of The Deep Sea Market, (2019). Retrieved from https://www.marineinsight.com/shipping-news/top10shipping-lines-control-almost-90-deep-sea-market/.

[41] Ward, R., (2017). Maersk Gets Green Light on Hamburg Süd Takeover. Retrieved from https://www.joc.com/maritimenews/container-lines/hamburg-sud/maersk-gets-green-lighthamburg-sud-takeover_20170925.html.

[42] Maersk Line, MSC and HMM Enter Strategic Cooperation, (2016). Retrieved from https://worldmaritimenews.com/archives/208399/maersk-linemsc-and-hmm-enter-strategic-cooperation/.

[43] Wan Hai Lines, K Line and PIL Join Forces on Transpacific, (2016). Retrieved from https://worldmaritimenews.com/archives/190358/wan-hailines-k-line-and-pil-join-forces-on-transpacific/.

[44] Baker, J. (2018). Zim Enters Strategic Co-operation with Maersk and MSC. Retrieved from https://lloydslist.maritimeintelligence.informa.com/LL112347 1/Zim-enters-strategic-cooperation-with-Maersk-and-MSC.

[45] Merriam Webster on Line Dictionary, (2019). Retrieved from https://www.merriam webster.com/dictionary/commoditize.

[46] Juga, J., Pekkarinen, S., Kilpala, H., (2008). Strategic Positioning of Logistics Service Providers. International Journal of Logistics Research and Applications: A Leading Journal of Supply Chain Management, Vol. 11, No. 6, pp. 443-455.

[47] Lorange, P. (2001). Strategic Re-Thinking in Shipping Companies. Maritime Policy \& Management, Vol. 28, No. 1, pp. 23-32.

[48] Gadhia, H. K., Kotzab, H., Prockl, G., (2011). Levels of Internationalization in the Container Shipping Industry: An Assessment of the Port Networks of the Large Container Shipping Companies. Journal of Transport Geography, Vol. 19, pp. 1431-1442.

[49] Notteboom, T., \& Rodrigue, J. P., (2012). The Corporate
Geography of Global Terminal Operators. Maritime Policy \& Management, Vol. 39, No. 3, pp. 249-279.

[50] Barnard, B. (2017). Maersk Group Sells Oil and Gas Business. Retrieved from https://www.joc.com/maritimenews/container-lines/maersk-line/maersk-group-sells-oil-andgas-business_20170821.html.

[51] Reuters, (2018). Reshaped Maersk Looking to Compete Directly with UPS, Fedex. Retrieved from https://www.joc.com/maritime-news/container-lines/hamburgsud/maersk-gets-green-light-hamburg-sudtakeover_20170925.html.

[52] Gronholt-Pedersen, J., Nielsen E. G., (2018). Maersk to Merge Damco, Ocean Product Units. Retrieved from https://www.reuters.com/article/us-maersk-strategy/maersk-tomerge-damco-ocean-product-units-idUSKCN1LZ0YO.

[53] APM Terminal, (2019). Retrieved from https://www.apmterminals.com/en/about/our-company.

[54] Lloyd's List, (2018). 100 Ports. Maritime Intelligence Informa. Retrieved from https://transportationstore.informa.com/wpcontent/uploads/woocommerce_uploads/2018/09/LL-TopPorts-sampler.pdf.

[55] Paris, C., (2019). CMA CGM Pursues \$1.65 Billion Deal for Ceva Logistics. Retrieved from https://www.wsj.com/articles/cma-cgm-launches-1-billiontakeover-offer-for-ceva-logistics-11549980384.

[56] CMA-CGM, (2019). Retrieved from CMA-CGM, 2019. Retrieved from https://www.cmacgm-group.com/en/group/ata-glance/terminals.

[57] Cosco, (2019). $\quad$ Retrieved from https://ports.coscoshipping.com/en/Businesses/Portfolio/\#Gre aterChinaTerminals.

[58] Knowler, G. (2018). Hapag-Lloyd Goes against Global Carriers' Terminal-Owning Strategy. Retrieved from https://www.joc.com/port-news/hapag-lloyd-rejects-globalcarriers-terminal-owning-strategy_20180222.html.

[59] Niamie', O., Germain, O., (2014). Strategies in Shipping Industry A Review of "Strategic Management Papers" in Academic Journals, Esg UQAM.

[60] Yang Ming Line, n. d. Yang Ming Line (2019). Retrieved from https://www.joc.com/maritime-news/container-lines/yangming-line. Accesses on 2 September 2019.

[61] Hyudai M. M., (2019). Retrieved from http://www.hmm21.com/cms/company/engn/container/introdu ction/index.jsp.

[62] PIL, (2019). Retrieved from https://www.pilship.com/en-ourservice-network-pil-pacific-international-lines/112.html.

[63] ZIM, (2019). Retrieved from https://www.zim.com/schedules/trades.

[64] Panayides, P. M., (2013). Competitive Strategies and Organizational Performance in Ship Management. Maritime Policy and Management, Vol. 30, No. 2, pp. 123-140.

[65] Markides, V., Holweg, M. (2006). On the Diversification of International Freight Forwarders. A UK Perspective. International Journal of Physical Distribution \& Logistics Management, Vol. 36, No. 5, pp. 336-359. 